\title{
Іван САВЧУК
}

кандидат географічних наук, старший науковий співробітник,

Національний університет оборони України ім. І.Черняховського

(Київ, Україна), ivansavchuk@yahoo.com

ORCID: https://orcid.org/oooo-0003-3779-0467

\section{Становлення геоісторіiі як міждисциплінарного напряму у суспільних науках Франції другої половини XX ст.}

DOI: https://doi.org/10.15407/uhj202I.02.I54

УДК: 911.3:930

\begin{abstract}
Анотація. Мета статті - визначення основних теоретичних та методологічних підходів геоісторії. Для цього було поставлено такі завдання: розкриття суті епістемології цього міждисциплінарного напряму за часів ії заснування; стислий аналіз основних праць Ф.Броделя, П.Шоню, Е. Ле Руа Ладюрі, Ж. Ле Гоффа. Методологія в дослідженні міждисциплінарних наукових напрямів спирається на вивченні насамперед оригінальних авторських текстів, їх критичному аналізі, що на основі порівняльного розгляду дозволяє виявити теоретикометодологічну цінність відповідних наукових доробків. Наукова новизна. Акцентовано увагу на тому, що у сучасній історичній науці Украӥни дослідження господарського минулого з позицій міждисциплінарних наукових напрацювань є рідкісними винятками із загального мейнстриму щодо студій та інтерпретації переважно політичних процесів, подій, явищ минулого. У цілому вони написані з традиційних позицій. Оригінальність і теоретико-методологічна цілісність геоісторичного підходу загальновизнана у світовій науці. Иого впровадження у вітчизняні дослідження, особливо у царині історії та географії, дозволить краще зрозуміти не лише економічний розвиток України в минулому, але й на сучасному етапі. Показано епістемологічну специфіку відповідних напрацювань Ф.Броделя та його учнів і соратників П.Шоню, Е. Ле Руа Ладюрі, Ж. Ле Гоффа. Висновки. Для етапу становлення геоісторії як наукового напряму характерні такі теоретико-методологічні особливості: геоісторія вбачається як історична наука, що спирається на методи і знання з фізичної географії для розкриття особливостей впливу на людську цивілізацію впродовж «довгої тривалості» основних характеристик клімату, рельєфу, природних особливостей великих фізико-географічних регіонів світу; теоретичною основою напряму виступає категорія «довгої тривалості», що виявляється через розкриття основних структур суспільства, сукупності яких формують суперструктури - цивілізацію і світ-економіку, що призводять до появи глобалізації як інтеграційного процесу; повільні зміни історичних процесів (насамперед соціальних, демографічних, економічних основ традиційного суспільства) дозволяють обгрунтувати тезу про «довге середньовіччя» як специфічний феномен у розвитку західноєвропейської цивілізації.
\end{abstract}

Ключові слова: геоісторія, геополітика, геокономіка, «довга тривалість», Бродель, Шоню, Ле Руа Ладюрі, Ле Гофф.

Велика роль у сучасних дослідженнях минулого належить міждисциплінарним підходам, в яких поєднуються в єдине ціле теоретичні напрацювання, методологія й методика (епістемологія) різних наук. Таким чином досягається комплексність у розумінні процесів та явищ, що мали місце в минулому. Саме це притаманне науковій школі геоісторії, представники якої широко застосовують епістемологію різних наук для пояснення особливостей розвитку минулого й сучасного світу. 
Свого часу ми вперше у вітчизняній науці зробили стислий виклад основних теоретико-методологічних особливостей наукової школи геоісторіїг. Слід нагадати, що геоісторія як окремий міждисциплінарний напрям була сформована Ф.Броделем ще в його першій фундаментальній монографії про світ Середземномор'я². Головні теоретико-методологічні положення цього нового напряму науки найповніше представлено у великих працях

У радянські часи ідеї Ф.Броделя аналізувалися та критикувалися з позицій марксизму в рамках вивчення наукової школи «Анналів» . Типовою $€$ послідовна критика з боку А.Я.Гуревича, котрий побачив у геоісторії лише «економіко-географічний детермінізм»5 , при цьому не навівши жодних цитат із праць Ф.Броделя ${ }^{6}$. Такого різновиду географічного детермінізму немає в географії, хоча саме посилання на географічний детермінізм було не випадковим звинуваченням, адже в радянський період його таврували як «ворожий напрям буржуазної науки»7 і відповідна заява вподібнювалася винесенню обвинувального вироку. Тому дивним виглядає в пострадянський час твердження, після публікації всіх великих праць Ф.Броделя російською мовою, що його «геоісторія» являє собою «поєднання економічного матеріалізму з географічним детермінізмом» ${ }^{8}$ та що він «радикально ревізував методологію Февра і Блока в іiі головному, центральному пункті»9, тож наступне покоління школи «Анналів» відвернулося від нього, повернувшись до основ школи Февра - Блока. Це викликає подив та нагадує радянські методи огульної критики. При цьому сам А.Я.Гуревич демонстрував цілковите незнання концепції посибілізму, зводячи ії до пасивного очікування ${ }^{\text {Io }}$ І Із такою категоричністю важко погодитися, адже Ф.Бродель сформувався як учений на класичних працях і лекціях видатних представників французької історії й географії та просто не міг працювати на позиціях географічного детермінізму, який зазнав дошкульної критики вперше саме з боку представників наукової школи

\footnotetext{
Савиук I.Г. Розвиток господарської діяльності на території сучасної України у просторі і часі. - К., 2019. - С.9-10; Його ж. Основні наукові підходи до вивчення просторово-галузевого розвитку господарської діяльності // Український історичний журнал. - 2018. - №2. - С.112-113.

Braudel F. La Méditerranée et le monde méditerranéen à l'époque de Philippe II: En 3 vol. - Paris, 1949 (poc. пер.: Бродель Ф. Средиземное море и средиземноморский мир в эпоху Филиппа II: В 3 ч. - Москва, 2002-2004). 3 огляду на можливий мовний бар'єр для українського читача, посилання на теоретико-методологічні напрацювання іноземних колег переважно подано за перекладами українською та російською мовами. Публікації іншими мовами - за відсутності такого перекладу.

3 Бродель Ф. Средиземное море и средиземноморский мир в эпоху Филиппа II: в 3-х ч. - Москва, 2002-2004; Eго же. Что такое Франция? Люди и вещи: В 2 т., 3 кн. - Москва, 1994; Бродель Ф. Матеріальна цивілізація, економіка і капіталізм, XV-XVIII ст.: У 3 т. - К., 1999.

4 АФанасвев Ю.Н. Историзм против эклектики. - Москва, 1980; Гуревич А.Я. Исторический синтез и школа «Анналов». - Москва, 1993; Далин В.М. Историки Франции XIX-XX вв. - Москва, 1981; Соколова М.Н. Современная французская историография. - Москва, 1979; Её же. Историческая теория Фернана Броделя // Французский ежегодник: 1972 г. - Москва, 1974.

Гуревич А.Я. Фернан Бродель, певец Средиземноморья и «времени большой длительности»// Бродель Ф. Средиземное море и средиземноморский мир в эпоху Филиппа II. - Ч.ІІІ: События. Политика. Люди. - Москва, 2004. - C.515.

6 Про роль географічного детермінізму у працях Ф.Броделя див. докл.: Dosse F. La ressource géographique en histoire // Espaces Temps. - 1998. - №68/70. Histoire/géographie, 2: Les promesses du désordre. - P.109-125; Lacoste Y. Braudel géographe / Lire Braudel. - Paris, 1988. - P.171-218; Ribeiro G. La genèse de la géohistoire chez Fernand Braudel: un chapitre de l’histoire de la pensée géographique // Annales Géographique. - 2012. - №686. - P.329-346.

Див. критику географічного детермінізму з позицій радянської географії: Саушкин Ю.Г. Экономическая география: история, теория, методы, практика. - Москва, 1973. - С.74-75; Семевский Б.Н. Введение в экономическую географию. - Ленинград, 1976. - С.19-23; Исаченко А.Г. Развитие географических идей. - Москва, 1971. - С.194, 235, $250,281,286,340-341$.

8 Гуревич А.Я. Фернан Бродель... - С.524.

9 Там же. - C.531.

10 Там же. - C.522.
} 
П. Відаля де ла Блаша". Фундатор наукової географічної школи у Франції ще г9о2 р. обгрунтував на противагу географічному детермінізму концепцію посибілізму ${ }^{12}$. Саме на його студії Ф.Бродель посилався у своїх монографіях. Наприклад, в останній великій праці «Ідентичність Франції» (1986 р.) він стверджував, що «єдність Франції та, зрозуміло, іï історія стверджуються по-справжньому не з Жанною д’Арк і навіть не з Французькою революцією, а безсумнівно пізніше, із розвитком залізничного зв'язку в його найкращі часи і з поширенням початкової школи»³. 3 останнього значного прижиттєвого дослідження Ф.Броделя чітко видно, що він не приймає засади географічного детермінізму (тобто, що весь хід історії та географічне середовище підготували й утвердили неминучість появи Франції в їі сучасних кордонах), а навпаки - прямо вказує на те, що сучасна Франція чи будь-яка інша країна виникли та утвердились як наслідок ланцюжка історичних подій, що відбувалися в рамках змін географічного середовища під впливом поетапного розвитку техніки, технологій, певних політикоекономічних подій і процесів ${ }^{14}$.

Востаннє російськомовний читач міг ознайомитися з науковим доробком Ф.Броделя завдяки статті $Є$. Браун ${ }^{15}$, яка $€$ радше науковим оглядом, аніж критикою. На теренах СНД найбільш повна сучасна наукова публікація щодо наукового доробку й життєвого шляху цього відомого вченого належить В.П.Смирнову, котрий стверджує: «Напрям [...] дослідження, об’єднавши історію й географію, Бродель означив запровадженим ним терміном “геоісторія”. За його концепцією, степи й гори, підняття та низовини, моря, ліси, ріки й інші географічні структури визначають рамки діяльності людини, шляхи сполучення, а, відповідно, і торгівлі; розміщення та темпи зростання міст. На їх основі виникають повільно змінювані економічні й соціальні структури: суспільство, держава, цивілізація. Вони слугують фундаментом для порівняно швидкозмінних, “кон’юнктурних” політичних подій, зіставних за своєю тривалістю з часом людського життя ${ }^{16}$.

Загалом вітчизняна історична та географічна науки при вивченні економічних процесів минулого все ще спираються переважно на історико-географічні напрацювання представників російської (радянської) науки. Вельми показова тут відсутність статті «Геоісторія» в «Енциклопедії історії України». Так само у цій фундаментальній колективній праці, яка відображає сучасний стан розвитку вітчизняної історичної науки, відсутня стаття про фундатора згаданого наукового напряму Ф.Броделя ${ }^{17}$. При цьому про теоретико-методологічну специфіку праць з історичної географії не згадано в тексті відповідної статті енциклопедії ${ }^{18}$. Також немає посилань на перекладені та видані в Україні його фундаментальні праці. Концептуальне поняття «довгої тривалості», а не «процесів великої тривалості», як перекладає К.Ю.Галушко, віднесено до напряму альтернативної історії, а не виділено в окремий науковий напрям чи школуг ${ }^{19}$ При цьому відсутні жодні посилання на праці українських істориків із цього

\footnotetext{
11 Безпосереднє посилання на саму концепцію посибілізму див.: Бродель Ф. Ідентичність Франції: У 3 кн. - Кн.1: Простір та історія. - К., 2013. - С.234.

12 Савиук I. Посибілізм // Екологічна енциклопедія: У 3 т. - Т.3 (О-Я). - К., 2008. - С.126.

13 Див. безпосереднє посилання на самого П. Відаля де ла Блаша: Бродель Ф. Ідентичність Франції. - Кн.1. - С.234.

14 У розд. 3 «Географія, чи саме вона вигадала Францію?» Ф.Бродель писав: «Вирішальний елемент - не земля, природа чи середовище, - а історія, людина - людина у полоні неї самої, оскільки вона - спадкоємець, продовжувач дій, справ і вчинків, технік і традицій тих, хто передував їй на їі власній території та змінив її пейзаж» (див.: Бродель Ф. Ідентичність Франції. - Кн.1. - С.233). 15 Браун Е. Школа Анналов - «Новая историческая наука» // Анналы экономической и социальной истории: Избранное. - Москва, 2007. - С.18-19.

16 Смирнов В.П. Фернан Бродель: жизнь и труды // Французский ежегодник: 2002 г. - Москва, 2002.

17 Плахонін А.Г. Анналів школа // Енциклопедія історії України. - Т.1 (А-В). - К., 2003.

18 Бачинська О.А. Географія історична // Там само. - Т.2 (Г-Д). - К., 2004.

19 Галушко К.Ю. Альтернативне тлумачення історії // Там само. - Т.1 (А-В).
} 
питання ${ }^{20}$. І це не дивно, адже не лише в наукових статтях ${ }^{21}$, а й у посібниках ${ }^{22}$ i курсах з історичної географії у вишах України 23 відсутні посилання на переклади українською та російською мовами монографій Ф.Броделя ${ }^{24}$. Водночас у них $€$ посилання на праці іноземних істориків початку ХХ ст., які чомусь слід вивчати для сучасного розуміння стану розвитку історичної географії, що $є$ нонсенсом ${ }^{25}$. Винятком стали посібники Ж.-Б.Дюпон-Мельниченко й Л.Закшільняка, де стисло розкрито сутність наукового методу саме $\Phi$.Броделя ${ }^{26}$. Така невідповідність між світовим визнанням наукової школи геоісторії та доволі короткими відомостями про неї у вітчизняній історіографії вказує на відсутність бажання ознайомитися з напрацюваннями сучасних іноземних фахівців із питань історичної географії й геоісторії ${ }^{27}$.

Одна з небагатьох, хто звернув увагу на епістемологічні особливості наукового доробку Ф.Броделя у царині геоісторії, $є$ Я.В.Верменич ${ }^{28}$. Проте в ії студії відсутні посилання як на його монографії, так і на сучасні дослідження з геоісторії у Франції. Власне, усупереч своїй назві стаття деталізує інтерпретацію відповідних напрацювань сучасних московських географів, які використано для аналізу регіонального культурного розвитку України ${ }^{29}$. Стислу характеристику першої монографії Ф.Броделя (1949 р.) подано у розвідці Б.Ачкіназі, але в ній відсутні посилання на сучасні французькі дослідження Середземномор'я з позицій геоісторії, що, безумовно, виглядає дуже дивно, адже не варто у 2012 р. писати рецензію на монографію 1949 р. без огляду сучасних відповідних напрацювань ${ }^{\circ}$, котрі розвивають та поглиблюють цю тему

20 Окремі українські історики, як уважає Г.Гоцуляк, провели свої дослідження в дусі наукової школи «Анналів» (див. їх огляд: Гощуляк Г.Г. «Нова історія» як одна з новітніх методологічних течій в історіографії // Вісник Черкаського ун-ту: Серія «Істор. науки». - Вип.192. - Черкаси, 2010. - С.3-7).

21 Див., напр., вітчизняні публікації з епістемології історичної географії: Верменич $Я$. Історична географія й регіонознавство: наступність і взаємодія // Істину встановлює суд історії: Збірник на пошану Ф.П.Шевченка. Т.2. - К., 2004. - С.488-517; Щодра О. Історична географія: еволюція поглядів на предмет і завдання студій // Вісник Львів. ун-ту: Серія історична. - Вип.48. - Л., 2013. - С.282-296; Ї̈ ж. Історична географія: формування предметного простору і структури дисципліни // Регіональна історія України. - Вип.9. - К., 2015. - С.159-174; Шищенко П., Муніч H. Історія географії та історична географія: галузі науки і навчальні дисципліни // Вісник Київ. нац. ун-ту імені Тараса Шевченка: Географія. - Вип.55. - К., 2008. - С.6-8.

22 Павленко Ю.В. Історія світової цивілізації: Соціокультурний розвиток людства. - К., 1996. - 360 с.; Котляр Ю.В. Історична географія: Спецкурс з історії. - Миколаїв, 2017. - 216 с.

${ }_{23}$ Напр.: Балабумевич Т.A., Тесленко I.A. Історична географія України: Методичні рекомендації і програма курсу. - К., 2015. - 50 с. ${ }_{24}$ Бродель Ф. Матеріальна цивілізація, економіка і капіталізм, XV-XVIII ст.: У 3 т. - К., 1997; Його ж. Ідентичність Франції: У 3 кн. - К., 2013-2014, 2017; Бродель Ф. Средиземное море и средиземноморский мир в эпоху Филиппа II: В 3 ч. - Москва, 2002-2004; Его же. Динамика капитализма. - Смоленск, 1993; Его же. Грамматика цивилизаций. Москва, 2008; Его же. Очерки истории. - Москва, 2015.

25 Так, автори відповідного курсу в Національному університеті «Києво-Могилянська академія» Т.Балабушевич і I.Тесленко (див. прим.23) пропонують студентам опрацювати як основну літературу з питань теорії й методології історичної географії працю: Gloger Z. Geografia historyczna ziem dawnej Polski. - Kraków, 1903 (!). Повне ігнорування сучасних напрацювань з епістемології геоісторії представниками НаУКМА викликає щонайменше подив. Так само немає посилань в їхньому посібнику на фундаментальні студії Ф.Броделя і при вивченні конкретних етапів в історичному розвитку України, хоча він неодноразово звертався у своїх монографіях до прикладів з ії території.

26 Дюпон-Мельниченко Ж.-Б., Ададуров В. Французька історіографія ХХ ст. - Л., 2001. - С.33-41; Зашкільняк Л. Сучасна світова історіографія. - Л., 2007. - С.35-37, 81-82.

27 Так, у своїй монографії Л.Пирогова-Таран (див.: Таран Л.В. Французька, російська і українська історіографія (70ті pp. XIX - поч. XXI ст.). - Ніжин, 2009. - 248 с.) розглядає розвиток уявлень лише французьких істориків-фахівців із Великої французької революції; у статті (див.: Пирогова-Таран Л.В. Етнологія та/чи історична антропологія // Український історичний журнал. - 2013. - №1. - С.119-124) згадує про спроби проведення досліджень із позицій школи «Анналів» у колишньому СРСР та побіжно говорить про геоісторію Ф.Броделя.

${ }_{28}$ Верменич Я. Від історичної географії до геоісторії: парадигми зближення // Історико-географічні дослідження в Україні. - Ч.13. - К., 2015. - С.11-26.

29 Показово, що у цій статті Я.Верменич відсутні жодні посилання на сучасних західних учених, а читача відіслано до відповідних класичних праць початку XX ст.

${ }_{30}$ Aчкіназі $Б$. Середземномор'я та його роль у трансформації західного суспільства в період раннього Нового часу (в контексті історичних уявлень Ф.Броделя) // Наукові записки [Кіровоград. держ. педагог. ун-ту ім. В.Винниченка]: Серія «Істор. науки». - Вип.16. - Кіровоград, 2012. - С.157-163. 
досліджень. Безумовно, що це не дозволяє усвідомити становлення геоісторії як нового наукового напряму. На противагу такій одиничній рецензії-рефлексії на цю першу велику працю Ф.Броделя в українській науці, російські історики й географи активно працюють у царині геоісторії ${ }^{11}$, зокрема важливою в епістемологічному плані $є$ стаття щодо ролі геоісторичного методу у сучасному вивченні економічного простору ${ }^{2}$.

Постає закономірне питання: чому вітчизняні історики лише епізодично використовують у власних напрацюваннях методологічні доробки своїх французьких колег, тоді як у російській історіографії вони стають предметом окремих докладних досліджень і гострих дискусій? Чи не зумовлено це інерцію радянського спадку, коли республіканська історіографія була культурною периферією щодо російсько-радянської з центрами в Москві та Ленінграді? Можливо, надання пріоритету поверненню репресованої спадщини істориків минувшини стало однією з причин такого стану у сучасній українській історичній науці? Тобто потрібен час, щоб сприйняти й розпочати використовувати відповідні знання? Чи це все ж закономірний результат переважного інтересу вітчизняних істориків до питань політичної історії, різних круглих дат та історіографічного дискурсу щодо інтерпретації саме подієвого переважно недавнього політичного минулого України? Важко дати однозначне пояснення. Значною мірою «війни пам'яті», трактувань подій нині панівний мейнстрим в українській істоpioграфії. Політичні явища минулого залишаються головними сюжетами більшості професійних публікацій вітчизняних істориків. Навіть філософські рефлексії щодо історії стосуються саме політичних аспектів історії. Безумовно, були поодинокі намагання поглянути на українську минувшину з інших позицій, але це залишається все ще на рівні побажань, а не грунтових праць.

У вітчизняній географії так само майже відсутні дослідження, які спиралися б на науковий доробок сучасних французьких фахівців, у тому числі геоісториків 33 . За наявності в періодичних і продовжених виданнях грунтовних статей, де викладено особливості сучасного розвитку французької географіїі4 ${ }^{34}$ в українській географії маємо єдину наукову публікацію, де з невідомих причин (навіть не посилаючись на праці фахівців з геоісторії міст ${ }^{35}$ ) геоісторію ототожнюють із соціальним історичним розвитком. Також не звертаються й до праць сучасних геоурбаністів, виданих в Україні з цього питання ${ }^{36}$, в яких стисло розкрито сутність геоісторичного дослідження. Це дозволяє нам зробити сумний висновок про небажання запроваджувати у вітчизняні географічні студії теоретико-методологічні напрацювання провідних наукових шкіл сучасної західної науки.

Проведений аналіз праць попередників дає всі підстави стверджувати, що у вітчизняній історичній і географічній науці відсутні публікації з епістемології геоісторії як окремого наукового напряму. У поодиноких публікаціях (як показано вище),

\footnotetext{
31 У цій статті ми не розглядаємо докладно сучасні напрацювання російських колег у сфері геоісторії.

32 Демъяненко А.Н., Дятлова Л.А., Украинский В.Н. Фернан Бродель и становление геоисторического метода в исследовании экономического пространства // Пространственная экономика. - 2013. - №3. - С.161-177.

33 На противагу цьому у сучасній російській географії відповідні напрацювання широко використовують при аналізі господарського розвитку (див., напр.: Трейвищ А.И. Город, район, страна и мир. Развитие России глазами страноведа. Москва, 2009. - 372 с.; География мирового развития. - Вып.1-3. - Москва, 2009-2010, 2016).

${ }_{34}$ Савчук I.Г. Основні тенденції розвитку французької географії у 70-80-х рр. XX ст. // Український географічний журнал. - 2004. - №3. - С.74-81; Його ж. Основні тенденції розвитку сучасної французької суспільної географії // Там само. - 2005. - №1. - С.31-36.

35 Левицька О. Геоісторичні зрізи розвитку планувальної структури міста Івано-Франківська // Економічна та соціальна географія. - Вип.75. - К., 2016. - С.74-79.

36 Лапорт A. Столицы государств - географические объекты // Український географічний журнал. - 2014. - №4. С.46-51; Руденко Л.Г., Савиук I.Г. Класифікація міжнародних функцій міст та їх прояв в Україні // Там само. - С.4-9; Савчук I. Створення образів Одеси і Санкт-Петербурга офіційною пропагандою Російської імперії // Сучасні проблеми дослідження, реставрації та збереження культурної спадщини. - Вип.8. - К., 2012. - С.467-474.
} 
де українські автори згадують поняття «геоісторія», вони використовують його як синонім «історичної географії», що є методологічною помилкою. У західній історії та географії ці два напрями давно визнано окремими науками, котрі мають власні об’єкт і предмет дослідження, специфіку застосування методологічного апарату до вивчення минулого ${ }^{37}$. Це дозволяє нам уважати представлену публікацію першою в українській науці саме з епістемологічної специфіки геоісторії як важливого сучасного міждисциплінарного напряму.

Провідний фахівець із сучасної епістемології геоісторії К.Граталу в розвитку цієї науки виділяє два основних етапи: до 1980-х рр., коли відповідні дослідження здійснювалися винятково істориками в рамках наукової школи «Анналів»; після 1980-х рр., коли дослідження почали переважно виконувати географи ${ }^{38}$, які розширили та доповнили концепцію геоісторії, залучивши напрацювання не лише економічної географії, а також новітніх напрямів - геополітики й геоекономіки.

Стисло розкриємо головні особливості відповідних досліджень у перший період розвитку геоісторії - за часів ії становлення, коли більшість напрацювань зробили саме історики. Отже геоісторія як міждисциплінарний науковий напрям почала формуватися від виходу у світ першої монографії Ф.Броделя в 1949 р. Відтоді відповідні дослідження набули поширення не лише у французькій, а й в інших національних наукових школах. На першому етапі студій не було багато, через необхідність опрацювання великої кількості архівних документів та опанування методів і результатів з інших наук (географія, метеорологія, математична статистика тощо). Тому прем'єрні дослідження виконував безпосередньо сам Ф.Бродель та його нечисленні учні. Розглянемо головні поняття концепції геоісторії, які вони розкрили у своїх публікаціях, із метою формування цілісного розуміння їі епістемологічної особливості.

Оригінальність і новаторство запропонованого Ф.Броделем підходу до вивчення минулого спиралося насамперед на концепцію «довгої тривалості». Найповніше iї теоретико-методологічну специфіку розкрито в однойменній статті ${ }^{39}$. Ф.Бродель протиставляв традиційний для історика подієвий поділ минулого за днями й роками серійних подій виявленню багаторічних тенденцій у розвитку. На його думку, навіть довгі економічні цикли Кондратьєва ${ }^{40}$ не $є$ достатнім методологічним інструментом для того, щоб виявити такі багатовікові тренди, адже ці цикли мають виразну господарську природу, тоді як сутність історичних циклів усе ще слід зрозуміти ${ }^{41}$. Їх виявлення можливе лише через дослідження структур у сенсі структурної антропології К.Леві-Стросса й Б.Маліновського. До них Ф.Бродель насамперед відносив географічні чинники, адже «людина впродовж століть є заручником клімату, рослинності, популяцій тварин, культур, рівноваги, яку тривалий час будували, за яку вона не може вийти без ризику втратити все» ${ }^{42}$. Особливо велике значення, на його думку, мало усвідомлення довгої тривалості в економічній історії. «Цикли, інтерцикли, структурні кризи приховують тим самим певну регулярну впорядкованість, стабільність систем, які окремі (вчені - I.C.) називають економічними цивілізаціями», котра, наприклад, тривала у Західній Європі чотири - п’ять століть на основі

\footnotetext{
37 Стисло про відмінності між геоісторією та історичною географією див.: Grataloup Ch. Géohistoire // Dictoinnaire de la géographie et de l'espace des société. - Paris, 2003. - P.401-402; Staszak J.-F. Historique (Géographie) // Ibid. - P.465-466.

38 Grataloup Ch. Géohistoire. - P.401.

39 Braudel F. La longue durée // Annales: Économies, Sociétés, Civilisations. - 1958. - №4. - P.725-753.

40 Щодо концепції довгих економічних циклів див.: Менъшиков С.М., Клименко Л.А. Длинные волны в экономике: Когда общество меняет кожу. - Москва, 1989. - 272 с.

${ }^{41}$ Braudel F. La longue durée. - P.730.

${ }^{42}$ Ibid. - P.731.
} 
торгівельного капіталізму до глибинної трансформації (промислової революції) в нову таку цивілізацію у XVIII ст., в якій ми продовжуємо існувати ${ }^{43}$. Розвиваючі цю думку Е. Ле Руа Ладюрі робив спробу проаналізувати соціально-економічну кризу у циклах різної тривалості, убачаючи в них типове явище людської історії ${ }^{44}$. Для їх вивчення необхідно визначити головні структури відповідного суспільства та економічну модель його функціонування ${ }^{45}$. Одну таку модель (для італійських міст епохи Відродження) розробив сам Ф.Бродель ${ }^{46}$, при цьому вона «у свою чергу, це спосіб пояснити структуру, інструмент контролю, порівняння, перевірки на достовірність і навіть існування заданої структури» ${ }^{47}$. Тому він пропонував вивчати не лише економічну історію, а й усю історію людства за допомогою математичних та картографічних методів, для того, щоб виявити ті довготривалі у часі закономірності, котрі $є$ в основі як економічних, так і політичних циклів, подій, процесів. Саме це Ф.Бродель намагався зробити у своїх подальших працях.

Як указує Є.Браун, головним у геоісторії є аналіз подій у рамках довгої тривалості природно-географічного й суспільного рівнів ${ }^{48}$. Перший рівень - «історія стабільних, практично нерухомих структур. На соціальному рівні час рухається вкрай повільно [...] Нарешті, план подій передбачає звичайний хід історії, що твориться на двох перших глибинних рівнях» ${ }^{49}$. «Головне досягнення Броделя усвідомлення неодмінної важливості історико-географічного контексту, в якому знаходиться й розвивається той чи інший регіон, країна, континент», - стверджує Д.М.Замятін ${ }^{\text {sо }}$. При цьому, як наголошував сам Ф.Бродель: «Географія - це [...] наука про ландшафт [...] наукове вивчення природного чи географічного середовища $[\ldots]$ життя людей» ${ }^{\text {s1 }}$, а тому геоісторія «є дослідженням подвійного зв'язку від природи до людини й від людини до природи, вивчення дій і реакцій, що постійно перемішані, та нескінченно повторюються щоденно в реальності» ${ }^{52}$. Тому, стверджував Г.Рібейро, особливістю геоісторії (у броделівському ії первинному розумінні) було залучення лише знань із фізичної географії, методів відповідних досліджень, як допоміжної важливої дисципліни, підпорядкованої історичному вивченню довгої тривалостіз

Особливість теоретико-методологічної концепції геоісторії полягає у вивченні впливу повільних змін у часі процесів адаптації та поступового довготривалого перетворення населенням території, на якій воно мешкає, на розвиток суспільства. Такі ідеї були дуже рідкісними для радянської історичної географії. Так, лише I.А.Іодо писав: «Зрозуміти сучасність, розібратися у складній просторовій структуpi таких значних і складних матеріально-просторових структур, як місто чи регіон, можна лише на основі вивчення процесу становлення у часі головних характеристик простору: шляхом аналізу генезису. Неможливо приймати рішення з прогнозування перспективного стану просторових форм без виявлення й аналізу стійких тенденцій їх

43 Ibid. - P.733

${ }^{44}$ Le Roy Ladurie E. La crise et l'historien // Communications. - 1976. - №25: La notion de crise. - P.19-33.

${ }^{45}$ Braudel F. La longue durée. - P.740-741.

${ }_{46}$ Braudel F. La Méditerranée... - Vol.1. - P.264.

47 Braudel F. La longue durée. - P.746.

${ }_{48}$ Браун Е. Школа Анналов... - С.18-19.

49 Там же. - C.19.

sо Замятин Д.Н. Метагеография: Пространство образов и образы пространства. - Москва, 2004. - С.195.

${ }^{51}$ Braudel F. Les ambitions de l'histoire. - Paris, 1997. - P.74.

52 Ibid. - P.102.

53 Ribeiro G. La genèse... - P.335. 
розвитку у часі, оскільки майбутнє потрібно розглядати як продовження сучасності, так само, як сучасність зростає 3 минулого» ${ }^{54}$.

Методологічною особливістю геоісторії є акцент на роль того чи іншого феномену або просторового явища у світі-економіці. Остання категорія основна в розумінні особливостей теоретичних результатів подібних наукових досліджень. Підкреслюється важливість аналізу існуючих зв'язків та обміну між різними групами людей, що призводять до формування залежностей між ними в рамках просторово великої системи - світу-економіки, під котрою розуміють господарство «лише певної частини нашої планети в тій мірі, в якій вона утворює економічно єдине ціле» 55 . За Ф.Броделем вона має три головних ознаки: «займає певний географічний простір»; «завжди має полюс, центр, представлений панівним містом [...] можливе одночасне існування [...] двох центрів»; «складається з низки концентрично розташованих зон», що розміщені у відповідності з теорією «центр-периферія» ${ }^{56}$. Це дозволяє нам стверджувати, що геоісторичне дослідження буде неповним, якщо не використовувати теоретико-методичні положення геополітики й геоекономіки.

Найповніше, на нашу думку, вплив структур (в їх броделівському розумінні ${ }^{57}$ ) на геоісторичний розвиток у рамках великих регіонів проявляється при геополітичному та геоекономічному вивченні ролі, значення провідних центрів розвитку суспільства у субрегіонах світу - найбільших містах, існування яких невіддільне від впливу першої (за часом виникнення) такої суперструктури - інституту держави ${ }^{58}$.

Ф.Бродель уважав, що «міста і гроші породили сучасний світ» 99 , що «міста все більше й більше ставали головними провідниками громадської думки [...] жодна держава, модернізуючи свою владу, не може здійснювати іï без згоди суспільства. Тому монархія шукала підтримки міст» ${ }^{60}$. На особливостях просторового та соціального структурування ліонської буржуазії від часів першої фіксації в письмових документах буржуазних кварталів у XVIII ст. до І940-х рр., убачаючи у змінах щодо їх локації в місті вплив загальнодержавних політичних та економічних процесів, наголошував А.Шателан ${ }^{6}$.

Власне міста Ф.Бродель відносив до однієї зі структур, виділяючи також серед категорій цього рівня промисловість, види сполучення, торгівлю, капіталізм ${ }^{62}$. Останній (на його думку) мав прояв у «великій спекуляції (біржовій та нерухомістю), великих банках, великому промисловому виробництві [...], міжнародній торгівлі; [...] в особливих випадках, - у сільськогосподарському виробництві й навіть у транспорті», він «живе за рахунок суспільного ладу й, бувши суперником чи співучасником, перебував на рівних (або майже на рівних) з державою» ${ }^{63}$. Особливість геоісторичного дослідження таких структур - спроба пояснення сучасних процесів, що, власне, є методологічною рисою «розгляду історії у широкій часовій перспективі» ${ }^{64}$.

\footnotetext{
54 Иодо И.А. Преемственность временных этапов формирования материально-пространственных структур поселений и регионов // Тезисы докладов I секции VII съезда Географ. общества СССР «Географические основы формирования народно-хозяйственных комплексов и систем расселения». - Ленинград, 1980. - С.68-69.

55 Бродель Ф. Динамика капитализма. - С.84.

${ }_{56}$ Там же. - С.86-87.

57 Бродель Ф. Что такое Франция? ... - Кн.1. - С.20; Кн.2, ч.2. - С.175, 177, 240, 261, 291, 301, 340.

58 Там же. - Кн.2, ч.2. - С.240.

59 Бродель Ф. Динамика капитализма. - С.21.

${ }_{60}$ Бродель Ф. Что такое Франция? ... - Кн.2, ч.2. - С.185.

${ }^{61}$ Chatelain $A$. De l'histoire sociale à la géographie sociale: les horizons d'une géohistoire sociale de la bourgeoisie lyonnaise // Revue de géographie jointe au Bulletin de la Société de géographie de Lyon et de la région lyonnaise. - Vol.25, №2. - 1950. P.90-98.

${ }_{62}$ Бродель Ф. Что такое Франция? ... - Кн.2, ч.2. - С.175, 177, 240, 261, 291, 301, 340.

${ }_{63}$ Бродель Ф. Матеріальна цивілізація, економіка і капіталізм, XV-XVIII ст. - Т.3. - С.558.

${ }_{64}$ Бродель Ф. Что такое Франция? ... - Кн.2, ч.2. - С.176.
} 
Тому геоісторія (за Ф.Броделем) - «не лише застосування до сучасної ситуації й майбутніх держав схематизованої просторової історії», а навпаки, як стверджує Ш.Ігуне, $є$ «витягом із географії того спостереження за сучасними реальностями [...] змушуючи переосмислити знову, із використанням іï методів і духу, минулі події [...] створюючи справжню ретроспективну географію людини; зобов'язавши також географів [...] звернути більше уваги на час та істориків [...] зацікавитися простором і тим, що з ним пов'язане» ${ }^{65}$. Саме у цьому була особлива методологічна цінність геоісторії для географів, особливо фахівців у сфері економічної географії. Це обумовило швидку зацікавленість французьких географів епістемологією цього нового напряму, можливістю його широкого застосування у власних дослідженнях.

У методологічному аспекті є принципова відмінність геоісторичного підходу до вивчення території від традиційних для радянської й пострадянської географії підходів. Цей методологічний підхід спрямований на вивчення станів і трендів розвитку певного фрагменту території планети, що існує тривалий час. Геоісторія висуває вимогу розкрити сутність геоекономічних та геополітичних явищ і процесів, що відображають зв'язки, котрі існують довгий період, і причинно-наслідковий механізм, який викликав та підтримує їх просторово-часовий прояв. Причому, як підкреслював А.Рейно, «якщо час превалює над простором, то це геоісторія, а якщо простір над часом, то це “культурна” географія сучасності та історична географія минулого» ${ }^{66}$.

Ф.Бродель при геоісторичному аналізі Франції вказував на те, що в кожну історичну епоху змінювався головний вектор економічного розвитку країни ${ }^{67}$. Власне вплив таких змін у державах-метрополіях на розвиток віддалених залежних країн із позицій геоісторії першим розкрив Р.Ламонтань на прикладі Канади ${ }^{68}$. Не менш цінна у цьому аспекті праця Г.Блюме про довготривале функціонування моноспеціалізованого ареалу вирощення цукрової тростини в пониззі р. Міссісіпі ${ }^{69}$. Автор наголошував на тому, що якщо фізико-географічні умови зумовили межі ареалу поширення цукрової тростини, то специфіка державної політики США з підтримки моноспеціалізації на вирощенні цукрової тростини залежних країн Карибського басейну призвела до адаптації місцевих франкомовних виробників до коливань у зовнішній політиці цієї держави та їх підпорядкування інтересам англомовних власників цукрових підприємств, котрі переважно проживали в Нью-Йорку. Виділення великих (подібних до кондратьєвських) циклів із виробництва цукру дослідник напряму пов'язував із головними змінами у зовнішній і почасти внутрішній геополітиці цієї держави, що залежало від світових економічних циклів.

Геоісторичні студіювання Ф.Броделя найбільше вплинули на таких відомих істориків, як П.Шоню, Е. Ле Руа Ладюрі, Ж. Ле Гофф. У своїх публікаціях вони розвивали не лише практичні дослідження з вивчення змін природи та господарства, а й деталізували, формулювали нові епістемологічні аспекти цього міждисциплінарного напряму науки. Зокрема П.Шоню, який захистив дисертацію під керівництвом Ф.Броделя, розвивав напрям геоісторіїํㅜㄹ

\footnotetext{
65 Див.: Dictionnaire de la géographie. - Paris, 1974. - P.205.

${ }_{66}$ Reynaud A. La notion d'espace en géographie // Travaux de l'Institut Géographique de Reims. - 1971. - №5. - P.5.

${ }_{67}$ Бродель Ф. Что такое Франция? ... - Кн.2, ч.2. - С.338.

${ }_{68}$ Lamontagne R. Geohistoire du Canada // Revue d'histoire de l'Amerique francaise. - 1965. - №18(4). - P.534-540.

69 Blume H. Zuckerrohrambau am unteren Mississipi (Louisiana’s Sugar Bowl) (Münchner Geographische Hefte, №5). -

Kallmünz/Regensburg, 1954. - 69 S.

70 Він писав: «Геоісторія була, ще в історії, дуже довгим часом, майже геологічним, нерухомим часом, який, отже, діалектично був протилежністю короткому нервовому часу [...] звичному для історії» (див.: Chaunu P. Les dépassements de l'histoire quantitative: retrospective et perspective // Mélanges de la Casa de Velázquez. - 1972. - T.8. - P.657).
} 
струкції економічних і демографічних процесів у минулому (квантитативна історія)71. У власних теоретико-методологічних напрацюваннях він широко застосовував доробок свого вчителя, намагаючись виділити структури та розкрити роль і значення міст у становленні, розвитку економіки, суспільства Європи й Латинської Америки. Насамперед П.Шоню широко застосовував броделівське поняття «цивілізація» ${ }^{72}$ для пояснення сукупності інститутів і структур ${ }^{73}$, що разом породжують суперструктуру, повільно змінювану у часі та просторі, і методи квантитативної історії - для виділення й обгрунтування економетричних моделей, економічних циклів та їх різноманітного впливу на суспільство ${ }^{74}$. При цьому він чітко показував зв'язок між економічним піднесенням і розширенням меж держав у вигляді класичного геополітичного аналізу, уникаючи, однак, застосування самого цього терміна ${ }^{75}$. Це було зумовлено тим, що у французькій науці тривалий час поняття «геополітика» ототожнювався з концепцією обгрунтування територіальної експансії нацистської Німеччини ${ }^{76}$.

Е. Ле Руа Ладюрі був одним із найвідоміших учнів Ф.Броделя. Він велику увагу приділяв дослідженню ролі клімату та його змін у розвитку насамперед аграрних структур у Західній Європі за середньовіччя й нового часу77. Послідовно розвиваючі ідею Ф.Броделя про те, що фізико-географічне середовище було та залишається вирішальним у розвитку людства, яке мусить прилаштовуватися до змін клімату, а отже рельєфу та гідрографічної мережі, він намагався створити історію без людей. «Клімат $€$ функцією часу», - стверджував дослідник ${ }^{78}$, послідовно розвиваючи цю свою думку в монографіях ${ }^{79}$, численних статтях. Наприклад, у 1973 р. він обгрунтовував саме клімат як новий об’єкт історичного дослідження в рамках «специфічної історіографії природних умов, географічної історії чи геоісторії» ${ }^{80}$. Виступав із низкою новаторських теоретико-методологічних ідей у контексті розвитку геоісторії як «нерухомої історії» ${ }^{81}$ та «історії навколишнього середовища» (маючі на увазі клімат як природне явище $)^{82}$. Е. Ле Руа Ладюрі вперше висунув та обгрунтував тезу про те, що у Франції в період між 1300 і 1730 рр. була квазістабільна традиційна економіко-демографічна структура суспільства на основі розширеної статево-вікової моделі та сталої екомоделі

\footnotetext{
${ }^{71}$ Шоню П. Цивилизация классической Европы. - Екатеринбург, 2005. - 608 с.; Его же. Цивилизация Просвещения. Екатеринбург; Москва, 2008. - 688 с.; Его же. История Латинской Америки. - Москва, 2009. - 160 с.

72 «Використовуватимемо слово “цивілізація” тільки для культур, які досягли писемного рівня» (див.: Шоню П. Цивилизация Просвещения. - С.11).

73 Як стверджує В.Бабінцев, ії він «розуміє як просторово-часову локалізацію діалогу культур» і тому «П.Шоню, розвиваючи ідеї Ф.Броделя й Е.Лабрусса, відіграв велику роль у формулюванні головної методологічної парадигми школи “Анналів”, що має характер опозиції “структура - кон'юнктура” (див.: Бабинщев В.А. Окружность - нигде, центр - повсюду: Послесловие // Шоню П. Цивилизация классической Европы. - С.316).

74 Так, він стверджував, що різка зміна моди в епоху Просвітництва (згідно з розробленим Ф.Броделем законом двох соціальних ритмів у сфері одягу) зумовлена появою африканської сировини, що «зробило можливим таке багатство тканин і кольорів, якого сама Африка досягти не могла, але яке вона бажала та за яке платила дорогою ціною експортом людей. Раби для американських плантацій за килими, раби за цукор (у той час - показник великої розкоші), раби за барвники... Коло замкнулося» (див.: Шоню П. Цивилизация Просвещения. - С.185).

75 «Від 1689 р. на континенті все визначається англо-французьким протиборством, ставкою в якому слугує різноманіття далеких “кордонів”. Франція, яка переважає супротивника чисельно, але волею-неволею втягнута в боротьбу за підтримку континентальної рівноваги, урешті-решт утрачає завойовані позиції» (див.: Шоню П. Цивилизация Просвещения. - С.86).

76 Про відновлення геополітичних досліджень у Франції див.: Савчук І.Г. Основні тенденції... - С.74-81.

7 Ле Руа Ладюри Э. История климата с 1000 г. - Ленинград, 1971. - 280 с.; Его же. Монтайю, окситанская деревня (1294-1324). - Екатеринбург, 2001. - 541 с.

${ }_{78}$ Ле Руа Ладюри Э. История климата с 1000 г. - С.12.

79 Le Roy Ladurie E. Histoire économique et sociale de la France: En 2 t. - Paris, 1976; Idem. Histoire humaine et comparée du climat: En 3 t. - Paris, 2004, 2006, 2009.

${ }^{80}$ Le Roy Ladurie E. L'histoire sans les homes: le climat, nouveau domaine de Clio // Territoire de l'historien: En 2 vol. Vol.1 - Paris, 1973. - P.423.

${ }^{81}$ Le Roy Ladurie E. L’histoire immobile // Annales: Économies, Sociétés, Civilisations. - 1974. - №3. - P.673-692.

${ }_{82}$ Le Roy Ladurie E. Pour une histoire de l'environnement: la part du climat // Ibid. - 1970. - №5. - P.1459-1470.
} 
природокористування ${ }^{83}$, для котрої неврожаї зернових 1693-1694 рр. і 1709 р. стали вираженням «кліматичної катастрофи XVII ст., яку можна порівняти з першою чи другою світовими війнами XX ст.! ${ }^{84}$. Ці дослідження безумовно можна вважати предтечами сучасного напряму глобальної історії. Новаторським є також дослідження Е. Ле Руа Ладюрі й Ж.-П.Баррі (за кадастрами, картами землеволодінь) формування та існування до сьогодення гаруги як виразника певного типу традиційного аграрного виробництва ${ }^{85}$.

Погляди Ж. Ле Гоффа формувалися під впливом концепції «довгої тривалості» Ф.Броделя, яка знайшла своє продовження в його власній концепції «довготривалого середньовіччя», у рамках котрого він виділяв як певні економічні цикли більш-менш довгої тривалості, так і моделі господарського розвитку, окремо акцентуючи увагу на суттєвому впливі природного середовища на існування людини в ті часи ${ }^{86}$. Водночас учений намагався включити ментальність як один із чинників такого повільного економічного розвитку, що знайшло свій прояв у різному сприйнятті часу представниками традиційного західноєвропейського суспільства (а це призвело до виразної дихотомії між світами «верхів» і «низів» тогочасного суспільства). Тому обгрунтовування «довготривалого середньовіччя» спиралося не лише на соціально-економічну структуру суспільства, а й на його ментальність, що знайшло своє розкриття в його головній праці з медієвістики ${ }^{87}$. Історик поділяв броделівську концепцію світуекономіки, яку було застосовано для опису політичних, економічних і культурних подій в Європі, починаючі від XV ст. ${ }^{88}$

Таким чином, можна дійти висновку, що для першого етапу в розвитку геоісторії як окремого наукового напряму характерні наступні теоретико-методологічні особливості: І) геоісторія вбачається як історична наука, що спирається на методи і знання з фізичної географії для розкриття особливостей впливу на людську цивілізацію впродовж «довгої тривалості» основних характеристик клімату, рельєфу, природних особливостей великих фізико-географічних регіонів світу; 2) теоретичною основою цього наукового напряму є категорія «довгої тривалості», що розкривається через аналіз основних структур суспільства, які формують суперструктури - цивілізацію і світ-економіку, котрі призводять до виникнення глобалізації як інтеграційного процесу; 3) повільна змінюваність історичних процесів (насамперед соціальних, демографічних, економічних основ традиційного суспільства) дозволила обгрунтувати тезу про «довге середньовіччя» як специфічний феномен у розвитку західноєвропейської цивілізації.

3 огляду на відсутність праць українських істориків і географів у царині сучасних геоісторичних досліджень, перспективним $€$ науковий аналіз відповідних зарубіжних публікацій. Розгляд епістемології сучасних студій у сфері геоісторії дозволить краще зрозуміти доцільність створення міждисциплінарних наукових колективів, а це сприятиме новій інтерпретації вітчизняної минувшини та сучасних процесів у контексті глобальних соціальних, економічних, політичних змін.

${ }_{83}$ Le Roy Ladurie E. L'histoire immobile. - P.680-681.

${ }^{84}$ Le Roy Ladurie E. La nécessaire prise en compte de l'histoire du climat // Collection EDYTEM: Cahiers de géographie. 2004. - №2: Traverser les montagnes. - P.19.

${ }^{85}$ Le Roy Ladurie E., Barry J.-P. Histoire agricole et phytogéographie // Annales: Économies, Sociétés, Civilisations. - 1962. №3. - P.434-447.

${ }_{86}$ Ле ГофФЖ. Рождение Европы. - Москва, 2007. - С.7-8.

87 Ле ГоффЖ. Цивилизация средневекового Запада. - Москва, 1992. - 376 с.

88 «У XVI ст. зі встановленням регулярних зв’язків між Північною Європою, Фландрією, азіатським світом і великими італійськими портами (Генуя, Венеція) складається європейський світ-економіка, центром якого у XV ст. був Антверпен. Цей процес став першою серйозною глобалізацією після римської глобалізації античного світу» (див.: Ле ГоффЖ. Рождение Европы. - С.122-123). 


\section{REFERENCES}

1. Achkinazi, B. (2012). Seredzemnomorie ta yoho rol u transformatsii zakhidnoho suspilstva v period rannoho Novoho chasu (v konteksti istorychnykh uyavlen F.Brodelia). Naukovi zapysky [Kirovobrad. derzh. pedahoh. un-tu im. V.Vynnychenka]. Seriia: Istorychni nauky, 16, 157-163. [in Ukrainian].

2. Afanasyev, Yu.N. (1980). Istorizm protiv eklektiki. Moskva. [in Russian].

3. Bachynska, O.A. (2003). Heohrafiya istorychna. Entsyklopediia istorii Ukrainy (10 vol.). Kyiv. [in Ukrainian].

4. Balabushevych, T.A., Teslenko, I.A.(2015). Istorychna beobrafiia Ukrainy: Metodychni rekomendatsii iprobrama kursu. Kyiv. [in Ukrainian]. Braudel, F. (1949). La Méditerranée et le monde méditerranéen à l'époque de Philippe II. Paris. [in French].

Braudel, F. (1997). Les ambitions de l'bistoire. Paris. [in French].

Braudel, F. (1958). La longue durée. Annales: Économies, Sociétés, Civilisations, 4, 725-753. [in French].

Braun, E. (2007). Shkola Annalov - "Novaya istoricheskaya nauka”. Annaly ekonomicheskoy i sotsialnoy istorii, 18-19). Moskva. [in Russian]. Brodel, F. (1993). Dinamika kapitalizma. Smolensk. [in Russian].

10. Brodel, F. (1994). Chto takoye Frantsiya? Lyudi i veshchi (2 vols.). Moskva. [in Russian].

11. Brodel, F. (1998). Materialna tsyvilizatsiia, ekonomika i kapitalizm, XV-XVIII st. (3 vols.). Kyiv. [in Ukrainian].

12. Brodel, F. (2002-2004). Sredizemnoye more i sredizemnomorskiy mir v epokbu Filippa II (3 vols.). Moskva. [in Russian].

13. Brodel, F. (2008). Grammatika tsivilizatsiy. Moskva. [in Russian].

14. Brodel, F. (2013-2014, 2017). Identychnist Frantsii (3 vols.). Kyiv. [in Ukrainian].

15. Brodel, F. (2015). Ocherki istorii. Moskva. [in Russian].

16. Chatelain, A. (1950). De l'histoire sociale à la géographie sociale: les horizons d'une géohistoire sociale de la bourgeoisie lyonnaise. Revue de géographie jointe au Bulletin de la Société de géographie de Lyon et de la région lyonnaise, 25, 2, 90-98. [in French].

17. Chaunu, P. (1972). Les dépassements de l'histoire quantitative: retrospective et perspective. Mélanges de la Casa de Velázquez, 8 , 647-685. [in French].

18. Chonyu, P. (2005). Tsivilizatsiya klassichenskoy Evropy. Yekaterinburg. [in Russian]

19. Chonyu, P. (2008). Tsivilizatsiya Prosveshcheniya. Yekaterinburg; Moskva. [in Russian].

20. Chonyu, P. (2009). Istoriia Latinskoy Ameriki. Moskva. [in Russian].

21. Dalin, V.M. (1981). Istoriki Frantsii XIX-XXvv. Moskva. [in Russian].

22. Demyanenko, A.N., Dyatlova, L.A., Ukrainskiy, V.N. (2013). Fernan Brodel i stanovleniye geoistoricheskogo metoda v issledovanii ekonomicheskogo prostranstva. Prostranstvennaya ekonomika, 3, 161-177. [in Russian].

23. Diupon-Melnychenko, Zh.-B., Adadurov, V. (2001). Frantsuzka istoriohrafia XX st. Lviv. [in Ukrainian].

24. Gurevich, A.Ya. (2004). Fernan Brodel, pevets Sredizemnomorya i “vremeni bolshoy dlitelnosti”. Braudel, F. Sredizemnoye more $i$ sredizemnomorskiy mir vepokbu Filippa II, 3, 508-535. Moskva. [in Russian].

25. Halushko, K.Yu. (2003). Alternatyvne tlumachennia istorii. (2003-2013). Entsyklopediia istorii Ukrainy (10 vol.). Kyiv. [in Ukrainian].

26. Hotsuliak, H.H. (2010). «Nova istoriia» yak odna z novitnikh metodolohichnykh techii v istoriohrafii. Visnyk Cherkaskoho universytetu: Seriya «Istorychni nauky», 192, 3-7. [in Ukrainian].

27. Isachenko, A.G. (1971). Razvitiye geograficheskikh idey. Moskva. [in Russian].

28. Kotliar, Yu.V. (2017). Istorychna heohrafiya: Spetskurs z istorii. Mykolaiv. [in Ukrainian].

29. Lacoste, Y. (1988). Braudel géographe. Lire Braudel, 171-218. Paris. [in French].

30. Lamontagne, R. (1965). Geohistoire du Canada. Revue d'histoire de l'Amerique francaise, 18(4), 534-540. [in French].

31. Laporte, A. (2014). Stolitsy gosudarstv - geograficheskiye obyekty. Ukrainskyi heohrafichnyi zhurnal, 4, 46-51. [in Russian].

32. Le Goff, Zh. (1992). Tsivilizatsiya srednevekovogo Zapada. Moskva. [in Russian].

33. Le Goff, Zh. (2007). Rozhdeniye Evropy. Moskva. [in Russian].

34. Le Roy Ladurie, E. (1970). Pour une histoire de l'environnement: la part du climat. Annales: Économies, Sociétés, Civilisations, 5, 1459-1470. [in French].

35. Le Roy Ladurie, E. (1973). L'histoire sans les homes: le climat, nouveau domaine de Clio. Territoire de l'historien, 1. Paris. [in French].

36. Le Roy Ladurie, E. (1974). L'histoire immobile. Annales: Économies, Sociétés, Civilisations, 3, 673-692. [in French].

37. Le Roy Ladurie, E. (1976). Histoire économique et sociale de la France. Paris. [in French].

38. Le Roy Ladurie, E. (1976). La crise et l'historien. Communications, 25. La notion de crise, 19-33. [in French].

39. Le Roy Ladurie, E. (2004). La nécessaire prise en compte de l'histoire du climat. Collection EDYTEM: Cahiers de géographie 2. Traverser les montagnes, 13-25. [in French].

40. Le Roy Ladurie, E. (2004, 2006, 2009). Histoire humaine et comparée du climat. Paris. [in French].

41. Le Roy Ladurie, E., Barry, J.-P. (1962). Histoire agricole et phytogéographie. Annales: Économies, Sociétés, Civilisations, 3, 434-447. [in French].

42. Le Rua Ladyuri, E. (1971). Istoriya klimata 1000 goda. Leningrad. [in Russian].

43. Le Rua Ladyuri, E. (2001). Montayyu, oksitanskaya derevnya (1294-1324). Yekaterinburg. [in Russian].

44. Levytska, O. (2016). Heoistorychni zrizy rozvytku planuvalnoi struktury mista Ivano-Frankivska. Ekonomichna ta sotsialna beohrafiia, 75, 74-79. [in Ukrainian].

45. Menshikov, S.M., Klimenko, L.A. (1989). Dlinnyye volny vekonomike. Kogda obshchestvo menyayet kozhu. Moskva. [in Russian].

46. Pavlenko, Yu.V. (1996). Istoriia svitovoi tsyvilizatsii: Sotsiokulturnyi rozvytok liudstva. Kyiv. [in Ukrainian].

47. Plakhonin, A.H. (2003). Annaliv Shkola. Entsyklopediia istorii Ukrainy (10 vol.). Kyiv. [in Ukrainian].

48. Pyrohova-Taran, L.V. (2013). Etnolohiia ta/chy istorychna antropolohiia. Ukrainskyi istorychnyi zhurnal, 1, 119-124. [in Ukrainian].

49. Reynaud, A. (1971). La notion d'espace en géographie. Travaux de l'Institut Géographique de Reims, 5, 3-14. [in French].

50. Ribeiro, G. (2012). La genèse de la géohistoire chez Fernand Braudel: un chapitre de l'histoire de la pensée géographique. Annales Géographique, 686, 329-346. [in French].

51. Rudenko, L., Savchuk, I. (2014). Klasyfikatsiia mizhnarodnykh funktsii mist ta yikh proiav v Ukraini. Ukrainskyi heohrafichnyi zhurnal, 4, 4-9. [in Ukrainian].

52. Saushkin, Yu.G. (1973). Ekonomicheskaya geografiya: istoriya, teoriya, metody, praktika. Moskva. [in Russian].

53. Savchuk, I. (2004). Osnovni tendentsii rozvytku frantsuzkoi heohrafii u 70-80-kh rr. XX st. Ukrainskyi beobrafichnyi zhurnal, 3 , 74-81. [in Ukrainian].

54. Savchuk, I. (2005). Osnovni tendentsii rozvytku suchasnoi frantsuzkoi suspilnoi heohrafii. Ukrainskyi heohrafichnyi zhurnal, 1, 31-36. [in Ukrainian].

55. Savchuk, I. (2012). Stvorennia obraziv Odesy i Sankt-Peterburha ofitsiinoiu propahandoiu Rosiiskoi imperii. Suchasni problemy doslidzhennia, restavratsii ta zberezhennia kulturnoi spadshchyny, 8, 467-474. [in Ukrainian]. 
56. Savchuk, I. (2018). Osnovni naukovi pidkhody do vyvchennia prostorovo-haluzevoho rozvytku hospodarskoi diialnosti. Ukrainskyi istorychnyi zhurnal, 2, 112-113. [in Ukrainian].

57. Savchuk, I. (2019). Rozvytok hospodarskoi diialnosti na suchasnii Ukraini u prostori ta chasi. Kyiv. [in Ukrainian].

58. Semevskiy, B.N. (1976). Vvedeniye vekonomicheskuyu geografiyu. Leningrad. [in Russian].

59. Shchodra, O. (2013). Istorychna heohrafiia: evoliutsiia pohliadiv na predmet i zavdannia studii. Visnyk Lviv. un-tu: Seriya istorychna, 48, 282-296. [in Ukrainian].

60. Shchodra, O. (2015). Istorychna heohrafiia: formuvannia predmetnoho prostoru i struktury dystsypliny. Rebionalna istoriia Ukrainy, 9, 159-174. [in Ukrainian].

61. Shyshchenko, P., Munich, N. (2008). Istoriia heohrafii ta istorychna heohrafiia: haluzi nauky i navchalni dystsypliny. Visnyk Kyiv. nats. un-tu im. T.Shevchenka: Heohrafiia, 55, 6-8. [in Ukrainian].

62. Smirnov, V.P. (2002). Fernand Brodel: zhizn i trudy. Frantsuzskiy yezhegodnik: 2002. Moskva. [in Russian].

63. Sokolova, M.N. (1974). Istoricheskaya teoriya Fernana Brodelya. Frantsuzskiy yezhegodnik: 1972. Moskva. [in Russian].

64. Sokolova, M.N. (1979). Sovremennaya frantsuzskaya istoriografiya. Moskva. [in Russian].

65. Taran, L.V. (2009). Frantsuzka, rosiiska i ukrainska istoriobrafiia (70-ti rr. XIX - poch. XXI st.). Nizhyn. [in Ukrainian].

66. Treivish, A.I. (2009). Gorod, rayon, strana i mir. Razvitiye Rossii glazami stranoveda. Moskva. [in Russian].

67. Vermenych, Ya. (2004). Istorychna heohrafiia i rehionoznavstvo: nastupnist i vzaiemodiia. Istynu vstanovliuie sud istorii, 2, 488517. [in Ukrainian].

68. Vermenych, Ya. (2015). Vid istorychnoi heohrafii do heoistorii: paradyhmy zblyzhennia. Istoryko-beobrafichni doslidzhennia v Ukraini, 13, 11-26. [in Ukrainian].

69. Zamyatin, D.N. (2004). Metageografiya: Prostranstvo obrazov i obrazy prostranstva. Moskva. [in Russian].

70. Zashkilniak, L. (2007). Suchasna svitova istoriohrafiia. Lviv. [in Ukrainian].

\title{
Ivan SAVCHUK
}

Candidate of Geography Sciences (Ph. D. in Geography), Senior Research Fellow, National Defense University of Ukraine named after I.Cherniakhovskyi

(Kyiv, Ukraine), ivansavchuk@yahoo.com

ORCID: https://orcid.org/oooo-0oo3-3779-0467

\section{Formation of Geohistory As an Interdisciplinary Direction in French Humanities of the Second Half of the Twentieth Century}

\begin{abstract}
The purpose of the article is to determine the principal theoretical and methodological approaches to geohistory. The following tasks were set for this purpose: revealing the essence of the epistemology of this interdisciplinary science at the time of its foundation; a brief analysis of the principal works of F.Braudel, P.Chaunu, E. Le Roy Ladurie, J. Le Goff. The methodology is pointed out that in contemporary Ukrainian historical science, studies of the economic past from the point of view of interdisciplinary scientific developments are rare exceptions to the general trend of research and interpretation of mainstream political processes, events and phenomena of the past. In general, they are carried out on the basis of traditional positions. The novelty - originality and epistemological integrity of the geohistorical approach is internationally recognized by the world scientific community. Its implementation in national research, particularly in the field of history and geography, will lead to a better understanding not only of Ukraine's economic development in the past, but also to a better perception of relevant current processes. The epistemological specificity of the research of F.Braudel and his disciples P.Chaunu, E. Le Roy Ladurie, J. Le Goff is well present. Conclusion. This stage in the development of geohistory as a scientific direction is characterized by the following epistemological characteristics: geohistory is considered a historical science based on methods and knowledge of physical geography to reveal the characteristics of the impact on human civilization during the "longue durée" of the fundamental characteristics of climate, terrain, natural features of large physical and geographical regions of the world; the theoretical basis of the direction is the category of "longue durée", which is revealed by the study of the basic structures of society, which form the superstructures - civilization and world economy, leading to the emergence of globalization as an integration process; the low variability of historical processes (mainly the social, demographic, economic foundations of traditional society) has made it possible to justify the thesis of the "longest Middle Ages" as a specific phenomenon in the development of the civilization of Western Europe.
\end{abstract}

Keywords: geohistory, geopolitics, geoecomony, longue durée, Braudel, Chaunu, Le Roy Ladurie, Le Goff. 